\title{
Turkish Geoeconomics and Its Influence in Albania
}

\author{
Blendi Lami \\ Lecturer, European University of Tirana
}

\begin{abstract}
Geopolitics is often used in reference to the use of geography in determining and shaping the international relations/foreign policy agenda of individual nation states. According to the proponents of the concept of geopolitics, political predominance in the international political system is not just a question of the general power and human resources at a country's disposal, but also of the geographical undertones within which a particular country exercises its available chunks of power. The rise of geoeconomics as an eminent replacement to geopolitics even becomes more significant in place of Turkey owing to its geopolitical position. The country is strategically surrounded by Europe, Asia, the Middle East and former Soviet states. The dynamics provided by the geopolitical position Turkey ushered in increased calls for the country to take up an active role in its foreign policy endeavors, and with it, a utilization of geoeconomics as a formidable strategy to push for Turkey's agenda in the Balkan region, especially Albania. Based on the geoeconomic and geocultural conception of the Balkan region, Davutoglu, the architect of new Turkish foreign policy, contents that the only way Balkan states can maintain their strategic importance is by reestablishing their success through intensive political dialogues and pursuing integrated economic policies. These are the endeavors of a country keen on utilizing economic values and principles to cement its political power in the Balkan region, and supplement its political influence over Albanian territories.
\end{abstract}

Keywords: geoeconomics, international economic system, economic diplomacy, foreign policy strategy, strategic depth

\section{Introduction}

The field of international relations has witnessed immense changes especially in the post Cold War period. Such changes emanate from the fact that the end of the Cold War ushered in a completely new era in the global international system as represented by the rise and the consequent collapse of the Soviet Union and the inception of multi-polarity in the international political system. In addition to a realignment of the global political scene, the post Cold War period has also witnessed a rise in economic aspects and their roles in the international political scene or other, transformation of geopolitics to geoeconomics. Countries are now utilizing different economic aspects to bolster their presence in international relations. The case for economic values in international relations is further supplemented by the present day wave of globalization and increased bilateral economic and trade interactions among countries. Countries cannot resist the urge to forge formidable economic interactions among themselves given the fact that the international economic system is now more or less interconnected (Kiniklioglu, 2011).

However, borrowing from the precedents of the realist theory of international relations, state relations are guided by a number of principles. The first one is the need to maximize their selfish national state interests. A state would therefore, relate with another state depending on what such a relationship confers certain positive benefits in the form of state interests. State interests are also supplemented by the need to safeguard ones' existence through military developments and forging of good regional or global military relations. Finally, countries are also always keen on maximizing their political and economic power both within the global and regional scenes. Most international relations move by any state would confer one or all of these principles, at least, when viewed from a realist perspective (Larrabee, 2010).

State interactions in the Balkan region have attracted wide attentions in the global academic world partly due to its historical background, geopolitical position and significance in the politics of the Cold War period. At the centre stage of the theoretical inquiries on state interactions in the larger Balkan region and the former Ottoman Empire, are the relations between Turkey and a vast majority of its neighbors specifically Albania, Kosovo and Macedonia. The increased interest in the ensuing 
relations between Turkey and each of these countries is attributed to the fact that these countries largely share identical historical backgrounds cutting across their physical proximity, shared religious values and populations among others. Population wise, close to 1.3 million of the current Turkish population boasts of partial Albanian origins and there is also a considerable number of Turks in Kosovo (Akcakar, 2007).

Historically, Turkey has often emerged the strongest and high ranking of the above four countries, largely due to its geopolitical position, economic wellbeing and period of independence among other factors. The country has since tried to utilize its supreme position to amass an influence over most territories in the Balkan region and specifically, those territories occupied by Albanians. Different political regimes in Turkey have tried to review their country's foreign policy agenda to reflect the emerging global and regional political trends. Based on an aggregate of existing international relations literature, Turkey chose to pursue a rather passive and reconciliatory approach when relating with its immediate neighbors. Such a move was considered by the country's policy making clout as a sure way of safeguarding Turkey's territorial integrity and sovereignty in a rather tumultuous region (Bal, 2004).

The end of the cold war altered the international political scene thereby precipitating a revision of Turkey's historical approach in its relations with other countries in the Balkan region. Such a revision was represented by the taking up a more active role by the country in Balkan territories and most importantly, the adoption of a new economic and multidimensional approach in international relations. Emboldened by the significance of the Balkans region in politics, the new Turkish foreign policy strategy, under the stewardship of AKP and the strategic views of Ahmet Davatoglu, Turkey has once against reestablished itself as a force to reckon with in the Balkan region (Davutoglu, 2009).

At the centre stage of Turkey's new foreign policy approach are its economic capabilities and the consequent transition of the global international relations scene from the geopolitical principles to geoeconomic principles. In the wake of these developments, this paper seeks to look at the extent to which Turkey is playing with the card of geoeconomics in its political influence on Albania and other territories inhabited by Albanians, specifically, Kosovo and Macedonia. The paper is organized into four major sections including the literature review section, which gives a short review of previously works on the relations between Turkey and the above three territories. The literature review is followed by an analysis and discussion on geoconomics in Turkey's present day foreign policy in Kosovo, Macedonia and Albania. A short conclusion summarizes the main findings of the entire paper.

\section{Methodology}

\section{Purpose and objectives of this paper}

This paper focuses on explaining the basic concepts related to Turkish geoeconomics in Albania, as part of Turkey's foreign policy strategic vision. This is intended by the new principles of Turkish foreign policy and the "strategic depth" doctrine since the AKP came to power. Therefore, this study has a special importance because it identifies and analyzes the mechanisms explaining why Turkish policymakers have adopted these concepts during this period. In this regard, there is a special focus on the perception of actors, their discourses and strategic documents. In view of achieving the goal, the objectives in this paper are: analyzing key concepts that explain Turkish geoeconomics; analyzing Turkish and Albanian geopolitical elements; explaining the major shift in Turkey's foreign policy, providing the level of Turkish involvement in the Western Balkans; and analyzing how Turkey is currently playing the geoeconomic card.

\section{Research questions and hypothesis}

Basic research questions are: How are the principles of foreign policy materialized into Turkish influence in Albania? How is Turkey playing the geoeconomic card?

The basic hypothesis is: Geoeconomics, as part of Turkey's foreign policy strategic vision, has created direct influence in the Balkans, especially Albania and territories inhabited by Albanians.

Given that the main purpose of this paper discusses the influence of Turkish geoeconomics, the methodology used is based on qualitative approach - analysis of discourse - focused on the operationalization of key concepts. Due to holistic nature of the problem, the methodology used is based on secondary approach. Regarding secondary sources, the author has used some theoretical perspectives of well-known authors in the field of international relations and political science. Regarding the theories used, there is a combination between two perspectives of international relations: realism and liberalism. It is also used the geopolitical orientation, which means that researchers in this area build certain ideas of the 
country, and these ideas have political influence and reinforce their behavior; these are ideas that influence how we, the people, process our notions of countries and politics (Bryman, 2004, fq. 24).

\section{Literature Review: Historical Background and Development of Turkey's Foreign Policy towards Albania and other countries in the Larger Balkan region}

Historically, the Republic of Turkey has formulated its foreign policy along certain identical lines including the later 19th century Ottoman heritage, the safeguarding of a strong existence in the wake of the dismemberment of this particular empire, and finally, a push for the cementing of the country's legitimacy and territorial integrity in the international scene. In addition to this was also western positivism and rationalist orientation emanating from the country's position as newly founded republican state. All these developments have in one way or the other ensured that respective political regimes construct this particular country's foreign policy along the lines of security, territorial integrity and sovereignty (Buyukcolak, 1999).

Throughout the process of pushing for these main foreign policy agendas, Turkey is forced to progressively adopt the principles of geopolitics and cautious real public diplomacy as key shapers of its foreign policy for the later parts of the last century. The above factors greatly influenced Turkey's relations with most states in the Balkan Peninsular in the $20^{\text {th }}$ century. Turkish political authorities sought to maintain the status quo and prevent the escalation of any formal conflict with any of the Balkan states; a conflict capable of putting into risk the integral sovereignty status of the country. This explains why the country promoted its diplomatic endeavors through the establishment of strong multilateral relations with other states in the Balkan region (Deringil, 2004).

Major changes in the foreign policy agenda of Turkey have however been witnessed across different periods in the history of the world. The first of such changes, and one which partly disoriented the above outlined structure was the Second World War. In the views of Murinson (2006), the inception of the Word War II greatly reorganized the political structure at both the global and regional levels. By the time this war came to an end, power arrangements in the international political scene had changed greatly and a significant chunk of the Balkan region had lost its significance for Turkey in as far as its geostrategic endeavors were concerned (Dautivic, 2011).

Another major shift in Turkey's foreign policy strategies was realized in the course of the Cold War where the country became an important ally of the Western political alignment in the Balkan region. This particular realignment greatly went against the grains given that most countries in this region chose to align their foreign policy agenda with the Eastern socialist bloc. This meant that the country maintained seemingly limited ties with Balkan states during the Cold War period and the country was further forced to change its foreign policy interactions' model after the end of the Cold War. This was necessitated by the emergence of multi-polarity as the dominant model in the international political system (Larrabee, 2010).

Turkey was as result of the multi-polar global political structure, rendered with a wide range of foreign policy challenges including a questioning of the credibility of its largely traditional strategy in its foreign relations. In order to properly react to the changes brought about by the ensuing Cold War, Turkey streamlined its foreign policy and adopted a more passive and reactive approach, at east up to the early/mid 1990s when it began taking up a more assertive foreign policy approach, especially on matters involving the Balkan region. Such a shift was largely in response to the ensuing wars and security concerns in this region although this assertive approach was changed in the end of the $20^{\text {th }}$ and the beginning of the $21^{\text {st }}$ centuries (Szigetvári, 2012).

A final turn in Turkey's foreign policy strategy was realized after the 2002 elections and the rise to power by the Justice and Development Party (AKP). The ascendancy into power by the APK is often cited as representing a major shift in Turkey's strategy in the global political scene. This not only created a new foreign policy agenda for Turkey, as a country, but also invoked a much needed momentum to the Turkish foreign policy agenda (Uzer, 2010).

The chief drafter of the then new Turkish foreign policy was Professor Ahmet Davutoglu, who tooled over the country's chief foreign policy advisor's docket and was tasked with advising the Turkish prime minister. Davutoglu later took over a prime role after becoming Turkey's minister of foreign affairs in 2009, and later he became Prime Minister. Since its publication in 2001, his book, "Strategic Depth: Turkey's International Position" provided the basic principles and objectives of Turkey's present day foreign policy and has gone a long way in influencing the country's relations with Balkan countries and the rest of the world in the AKP regime (Bechev, 2012). 


\section{Geopolitics and the Rise of Geo-economics in International Relations}

Geopolitics is often used in reference to the use of geography in determining and shaping the international relations/foreign policy agenda of individual nation states. According to the proponents of the concept of geopolitics, political predominance in the international political system is not just a question of the general power and human resources at a country's disposal, but also of the geographical undertones within which a particular country exercises its available chunks of power. It is however worth noting that geography does not solely shape a country's conduct and relations with other countries, but rather does present countries and their individual policy makers with a path to align their foreign policy strategies with (Oktav, 2013).

Of major significance in the utilization of geopolitics in guiding a country's foreign policy agenda is the geopolitical code. This is rather the mapping of the main priorities, weaknesses and opportunities provided by the geography of a given country. Here, a country has to critically asses it neighbors, potential enemies, and ways of fostering good ties with its friends at the same time countering the prospective threats of its enemies. Forging a formidable way to achieve all these however calls for the utilization of a number of values ranging from economic strengths, cultural values and educational linkages among others (Uzer, 2010).

The rise of geoeconomics as an eminent replacement to geopolitics even becomes more significant in place of Turkey owing to its geopolitical position. The country is strategically surrounded by Europe, Asia, the Middle East and former Soviet states. This does not only provide opportunities for the country, but also presents with it a wide range of difficulties in as far as the drafting of a sound foreign policy strategy is concerned. The dynamics provided by the geopolitical position Turkey ushered in increased calls for the country to take up an active role in its foreign policy endeavors, and with it, a utilization of geoeconomics as a formidable strategy to push for Turkey's agenda in the Balkan region. Such calls and the coming into the fore front of Ahmet Davotoglu ensured that Turkey had to redefine geopolitics and adopt more of geoeconomics, especially in its relations with its immediate neighbors (Oksuz, 2007).

\section{Turkey's Relations with the Balkans}

What constitutes the present day Balkan countries was once under the traditional Ottoman Empire, at least up to the end of the Balkan Wars in the early $20^{\text {th }}$ century. Ottoman viewed the Balkan region as part of his most treasured territories both politically and economically. These territories not only provided an avenue through which Ottoman could reach out to Europe, but also presented good grounds for the expansion of the larger Ottoman Empire thereby raising the stakes of the same empire in Europe. The Balkan region would however serve as the main naval for the consequent decline of the Ottoman Empire. Additionally, the foundation of the present day Nation state of Turkey, owes its existence to the Balkan region given the fact that nationalist and reformist escapades leading up to the creation of Turkey as a nation state, traces their origins in the Balkan territories (Winrow, 1993).

According to Oktav (2013), the Balkan wars, the dissolution of the Ottoman Empire, and the First World War complicated the international relations and political situation of the newly created Turkish state. This ensured that Turkey would concentrate on internal stabilization, maintenance of state sovereignty and territorial integrity as its main international relations priority as envisaged in the details of Treaty of Lausanne signed in 1923. Turkey was as a result of these particular foreign policy priorities, less focused on territorial expansion or other, a scramble over the former Ottoman Empire. The country was rather keen on co-existing with its neighborhood Balkan states under the principles of state cooperation and territorial integrity.

To push for the realization of state sovereignty, Turkey signed friendship treaties with the Balkan states of Albania and Yugoslavia in 1923 and 1925 respectively. These particular treaties coupled with similar two other identical ones with Bulgaria and Greece in the late 1930s, further emphasized Turkey's foreign policy priorities in the Balkan region immediately after its establishment as an independent nation state. In the views of Winrow (1993), the seemingly less aggressive foreign policy course pursued by Turkey in the late 1920s and early 1930s can be attributed to the fact that the country was yet to establish itself as regional political and economic powerhouse. Limited capabilities therefore ensured that Turkey could not categorically align its foreign policy agenda with the precedents of geoeconomics (Grigoriadis, 2010).

The great economic crisis of the late 1920s provided a good opportunity for Turkey to pursue an aggressive foreign policy towards the Balkan states. This was firstly necessitated by the fact that the region lacked a strong economic and political leader. This presented the first clear chance for Turkey to pursue the geoeconomic approach in its relations with a good 
number of the Balkan states as indicated by the establishment of strong bilateral relations between Turkey and some of these states. However, peace, political neutrality and a maintenance of the status quo still remained at the forefront of Turkey's foreign policy priority in as far as its relations with Balkan states were concerned (Szigetvári, 2012).

The politics of the Cold War period and consequent political realignments towards either the eastern or western blocs further represented another major shift in Turkey's foreign policy towards a good number of countries in the large Balkan region. During earlier times of the Cold War, the country was more or less keen on abolishing its political neutrality stance, possibly as a way of checking the spread of communism. This forced the country's foreign policy crusaders to develop a cold shoulder towards any Balkan state whose foreign policy agenda drifted towards Communism and the Soviet Union while maintaining some good ties with those states aligning themselves with the Western ideologies (Mitrovic, 2014).

The above trend was to be changed later in the late 1960s after western countries started opening up to their eastern counterparts. In response to this shift of course, Turkey became more open to the idea of re-establishing a new wave of ties with a good number of Balkan states through an expansion of trade and cultural ties. There was for instance an increase in the trade and economic interactions between Turkey and other Balkan states although these states accounted for less than two percent of Turkey's total imports and less than four percent of its exports.

Turkey began giving due emphasis on its economic wellbeing and that of its neighbors during the late 1980 s. This was demonstrated by the country's political leadership's inclination towards a push for the attainment of greater heights of economic liberalization both domestically and regionally. This course was further supplemented by the then emerging geostrategic significance of Yugoslavia following the collapse of the bipolar system after the end of the Cold War. Turkey got more concerned with the economic and political plight if Yugoslavia and its other Balkan neighbors thereby cementing the utilization of geoeconomics in its foreign policy (Pope, 2010).

\section{Davutoglu's Doctrine and Turkey's New Foreign Policy in Practice}

Immediately after the end of the Cold War, Turkey was forced to reconsider its foreign policy stance in a much changed post-Cold War period. There was seemingly a wave of uncertainty regarding the country's actual foreign policy path, especially when it came to its relations with the neighboring Balkan states. This precipitated a wave of reactions from different players both in the political and academic fields with most of them pushing for an adoption of a completely new Turkish foreign policy. A dominant figure in the push for a new Turkish foreign policy was Ahmet Davutoglu, whose work, as was noted earlier in this paper, formed the background for a new foreign policy strategy in Turkey. Davutoglu's key argument was that the collapse of the bipolar system led to seemingly major geopolitical and geoeconomic vacuums in the Balkan region and this provided a good opportunity for Turkey to re-establish itself as a political/economic power to reckon with in this region (Grigoriadis, 2010).

In one of his 2009 speeches, Davutoglu defined the Balkan region from a geopolitical, geoeconomic and geocultural perspectives. From a geoeconomic point of view, the Balkan region represents a "transaction area, " cutting across the sea and land borders. The Balkan is also representative of wide cultural interactions and major cultural diversities often come into the play in most Balkan countries' foreign policy endeavors.

Based on the above geoeconomic and geo-cultural conception of the Balkan region, Davutoglu contents that the only way Balkan states can maintain their strategic importance is by reestablishing their success through intensive political dialogues and pursuing integrated economic policies. Turkey's traditional legacy and position places it at the core of activities in the Balkan and it is therefore upon itself to oversee the state of affairs in this region (Hale, 2012).

At the center stage of Davutoglu's views, as demonstrated by his arguments in the book "Strategic Depth: Turkey's international position", was the taking up of an assertive economic role by Turkey in the Balkan region. His assumptions were actually built on the principles of Neo-Ottomanism and multi-dimensionality in foreign policy. New-Ottomanism was largely furthered by former Turkey president, Turgut Ozal and strongly dealt with the issue of economic liberalization and a cementing of Turkey's economic influence in the larger Balkan region (Mitrovic, 2014).

Since 2009, Turkey has formulated its foreign policy towards Balkan countries, along Davutoglu's ideas. The Balkan offers strategic geographical and economic advantages to Turkey partly due to its historical background. Countries in this region consequently aid Turkey's political ambitions in Europe and the country is therefore indebted to closely monitor economic, social and political developments in most of these countries, at least for its political benefits. Turkey's present day foreign 
policy is hinged on the principles of regional ownership and inclusiveness-attainable through a preservation of multiethnicity, economic integration and the construction of multi-cultural and multi-religious structures. The country has in turn shown major interests in the creation of good cooperation and integrative platforms as demonstrated by the formation of the Southeast European Cooperation Process (SEECP). The push towards integration has on the other hand laid the ground for Turkey to utilize the card of geoconomics, especially when it comes to its relations with Albanian-settled countries.

\section{Analysis}

\section{Geo-economics in Turkish Relations with Albania, Kosovo and Macedonia}

Turkey's adoption of geo-economics strategies to cement its political relations with countries in the Balkan territory is firstly indicated by its decision to sign a wide range of bilateral economic agreements with most of these countries. One of such agreements was signed between Turkey and the Republic of Macedonia in 1999 and was generally aimed at strengthening existing relations between the two countries, especially in the area of economic integration.

Apart from the signing of general economic and trade Agreements, Turkey's foreign trade with the above three countries has been on the rise from the onset of the $21^{\text {st }}$ century. The country's exports to almost all of these countries grew by a couple of percentages largely due to the signing of free trade agreements and Turkey's push towards cementing its economic wellbeing in the large Balkan region. Additionally, Turkey has more than doubled its foreign policy investments in Macedonia, Kosovo, and Albania. Within the larger Balkan region for instance, Turkey's foreign policy investment jumped from mere 30 million dollars in 2002 to close to 190 million dollars in 2011. Such increases indicate the seriousness with which Turkey is viewing geoeconomics as a formidable tool to cement its political influence over the Balkan countries. Kosovo enjoys the largest share of Turkey's foreign direct investments in the Balkan region.

From a country point of view, Turkey initially recognized the state of Macedonia immediately after the latter successfully caved out of Yugoslavia in 1991. According to most foreign policy scholars, Turkey's prospective pursuit for a geoeconomics approach in its foreign policy relations with Macedonia was largely supported by the fact that the latter was one of the least developed regions of Yugoslavia. The country faced brutal economic challenges and neither was it doing well socially, given the then ensuing ethnic squabbles pitting people of Albanian decent and other majority ethnic groups. From an international relations perspective, Macedonia was also reeling from the seemingly hostile political and economic policies adopted by Greece. Greece had objected the recognition of Macedonia by European Union countries and even curtailed EU's economic assistance to Macedonia (Szigetvári, 2012).

Staring at the pit of economic and social collapse, Macedonia had to establish some friendly economic and political ties with Turkey, the second country to recognize Macedonia as an independent state. The former took up this opportunity and laid the background for strong political and economic relations with Macedonia as firstly indicated by its position as the first state to open up a fully functional embassy in Macedonia (Mitrovic, 2014).

Turkey's utilization of the geoeconomics card is consequently highlighted by the swiftness with which the country took advantage of ensuing economic difficulties in Macedonia to cement its foreign policy and political influence over Macedonia. The country's seemingly strong will to cement its ties with Macedonia when the latter was still grappling with the problem of attaining a full international recognition, was informed by geo-economic motives. This should not however imply a disregard of Turkey's quest to safeguard the plight of its Turkish population in Macedonia. It is all the same worth admitting the fact that Macedonia was at this time facing more of an economic than a social challenge and Turkey's decision to build good ties with this state had more to do with economic factors than social factors.

Additionally, Turkey's geo-economics steps are further indicated by its active roles in the establishment of economic bilateral and multilateral agreements with Balkan states. For instance, the country was at the forefront in pushing for the establishment of the South East Europe Cooperative Initiative (SECI) in 1996, with the sole aim of advancing regional cooperation, especially in the economic and environmental areas. The country was at took active part in improving the $\mathrm{SECl}$ and even engineered the creation of a platform through which member countries could cooperate in stock exchange markets. This particular move generally represents the endeavors of a country keen on utilizing economic values and principles to cement its political power in the Balkan region, and by far, supplement its political influence over Albanian territories (Rubin \& Kirisci, 2001). 
Albania was more or less sailing through similar conditions with Macedonia. The country was for instance, one of the least developed Balkan states after the end of the Cold War largely as a result of its previous inclination towards communist economic policies on the course of the Cold War. There was therefore an urge to change the economic plight of the country by adopting market economy principles in the early 1990s - given the fact that Albania is one of the most significant territories for Turkey's foreign policy strategies in the larger Balkan region.

The significance of Albania to Turkey is shown by the fact that Albania was at the centre stage of the seemingly difficult relations between Turkey and Greece. In a sharp response to the ensuing political squabbles between Albania and Greece, Turkey quickly took the initiative of supplementing its political influence over Albania by signing a bilateral trade and economic Agreement with Albania in the late 1980s (Pope, 2010).

Progressive slow, but rather far reaching economic in-surges by Greece in Macedonia and Albania and the swiftness with which Turkey moved to counter Greece, further a go a long way in highlighting the extent to which Turkey played and is still playing with the card of geoeconomics to cement its political influence over Albania, Macedonia and Kosovo. For instance, significant investments by Greece in Macedonia and Albania at the beginning of the $21^{\text {st }}$ century precipitated a swift move by Turkey to cement its economic and political relations with the two countries above. Turkey was therefore keen on utilizing geoeconomics to fend off the prospective threat offered by Greece's ensuing political influence over Macedonia and Albania (Mitrovic, 2014).

As noted above, Turkey still considers Albania as one of its main economic partners in the larger Balkan region. This is because, Albania not only boasts of favorable investment opportunities, but also offers a good outlet between the Balkan region and other countries in Europe and the Mediterranean region. Realizing the economic potential and worthiness of Albania, Turkey has seized the opportunity and moved towards establishing strong trade and other commercial ties with this particular country and such ties have in one way or the other placed Turkey in a better place to master strong control over Albania and other Albanians' settled territories. The two countries have since the late 1980s sought to cement their trade and economic ties through the signing of the two trade/economic related agreements between 1986 and 1988 (Oksuz, 2007).

A similar free trade agreement between the two countries was also signed in May 2008. Although these agreements point out to seemingly mutually beneficial trade and economic interactions, Turkey has used the same agreements to bolster its political influence on Albania. These particular Agreements set the tone for an increase in Turkey's exports and foreign direct investments in Albania. Such moves definitely serve as representations of the former's push towards cementing her political influence on Albania. For instance, the 2008 Agreement gives Turkish exporters an upper hand in their trade endeavors with Albania and this definitely gives Turkey a formidable chance through which it can politically influence Albanians' inhabited territories (Szigetvári, 2012).

The 2008 Free Trade Agreement consequently provided an avenue through which Turkey could economically endear itself to Albania and consequently cement its political influences on a large part of the Balkan territory. In these agreements, Turkey offered what could be termed as economic and trade goodies to Albania as indicated by a decision to nullify custom duties on all Albanian originating commodities in exchange of only $80 \%$ customs duty waiver on Turkish goods in Albania. The fact that the terms of most agreements between Turkey and Albania offer significant advantages to Albania is a clear indication of Turkey's intentions to utilize the card of geoeconomics in its international relations with Albania (Mitrovic, 2014).

From a different perspective, Turkey has further taken advantage of the significance of the Agricultural sector to the economic prospects of Albania, and as a result, tries to get into trade/economic agreements with the latter, all with the aim of bettering its political influence on Albanians' inhabited territories in the large Balkan territory. To date, Turkey imports a wide range of agricultural products for Albania and such imports only supplement Turkey's political influence (Blitz, 2006).

However, Turkey is not the biggest export or import trade partner to Albania, but, the two countries still enjoy a boom in their trade and economic relations. For instance, Turkey was ranked among the top ten Albania's biggest export partners with an export market share of close to $2.0 \%$ in 2008 . This was way below the $11.8 \%$ and $6.6 \%$ export shares commanded by Greece and Kosovo respectively. The country ranks a little bit higher among Albania's leading import partners although this particular country's rank is still way below that of Greece and Italy. Based on these 2008 export and import market share figures, it is evident that Turkey is not necessarily the leading economic and trade partner to the state of Albania. 
However, it is only fair to acknowledge the fact that Turkey is partly using geoeconomic principles to supplement its political influence over Albania. It still ranks among the first three import partners to Albania and such a rank shows how the country is still keen on utilizing economic practices like trade partnerships to amass a considerable political influence on Albania and other neighboring states (Grigoriadis, 2010).

\section{Discussion}

The recently adopted, Turkish foreign policy strategy consequently goes a long way in highlighting the extent to which this country is committed to the utilization of geoeconomic principles to amass a significant influence on the Albanians' inhabited territories of Albania, Kosovo and Macedonia. Since Davutoglu's appointment as minister of foreign affairs, Turkey adopted a new foreign policy strategy built on five main operational and methodological principles (Davutoglu, 2008).

The first methodological principle guiding Turkey's foreign policy agenda promotes the establishment of good relations with neighboring states, purely based on a clearly set out vision. It is however the third methodological principle that sets the ground for the use of geoeconomic principles in Turkey's foreign policy, especially in the larger Balkan region. The third principle emphasizes on the use of instruments of soft power, and creating a balance between these same instruments and other hard ones, all with the aim of creating a new discourse and diplomatic approach whose main priority is "Turkey's civileconomic power" (Ozcan, 2008).

The above principle largely highlights the focus with which Turkey views economic practices as practical avenues through which the country can flex its muscles as far as amassing greater influence on Albania, Kosovo and Macedonia is concerned. From a different perspective, one of the 2009's Turkish foreign policy operative principles further leaves a wider room for the use of geoeconomics to bolster the country's political influence on Albania and its neighboring countries. This is basically what Davutoglu denotes to as the "zero problem policy towards Turkey's neighbors" and authorizes Turkish foreign policy implementers to maximize the country's cooperation with neighboring countries by utilizing both multilateral and bilateral cooperation measures (Kosebalaban, 2011).

Additionally, Turkey has also pursued the maintenance of high levels of activity across the social, political, military, and most importantly, economic divides. This new operational principle paves way for the conception of neighborhood as an opportunity rather than as a security threat and surely puts Turkey in a sole position to use existing economic avenues to marshal strong political influence over its neighbors. The newly incepted neighborhood approach consequently serves as a solid ground for soft power tools such as economic values in shaping the relations between Turkey and other Albanian territories. It is on the basis of this approach that the country has prioritized the improvement of its trade, energy and other economic-related interactions with its neighbors. Alongside the second operative principle is also a push for greater levels of regional economic integration as way of promoting peace and security in the large Balkan region (Elsie, 2010).

A major incentive for Turkey's new push towards marshalling a strong influence on Albania and its other Albanians' neighboring territories are the sure positive prospects wielded by the Turkish economy in the past few years. Turkey was ranked at position 16 in the world economy in 2010 and at the $18^{\text {th }}$ position in 2011. This seemingly good prospect in the country's economy has ensured that Turkish authorities embrace economic expansion as a key component of their country's foreign policy (Hale, 2012).

Turkey still views the line cutting across the geographical territories of Middle Bosnia, Kosovo, Albania, Macedonia and a significant part of Bulgaria, as a critical geocultural and geopolitical vein in the larger Balkan region. Turkish foreign policy makers are therefore keen on ensuring that this line remains intact. To attain this course, the country remains devoted to supporting Albania and other Albanian territories, and this support is always aimed at strengthening Turkey's political influence in the region (Pope, 2010).

Any consequent division of Albanians in the Balkan region will not only lead to their economic weakening, but also pave way for the disintegration of the traditional Ottoman legacy. Turkey is therefore bound to fend off any prospective disappearance of the Ottoman legacy since such a disappearance only implies significant reductions in the country's political influence in the Balkan region. The only way Turkey is to supplement its political influence in the region is by pursuing geoeconomics as a key driver of its foreign policy towards Albania and other Albanians' dominated territories. Geoeconomics principles offer a sure way through which Turkey can maintain internal stability in Albania, Kosovo and Macedonia, strengthen cultural identity in the Balkan region, and strengthen both social and economic connections among Albanians and between Albanians and other Muslim communities (Hale, 2012). 
The stake for Turkey is even much higher when it comes to its relations with Kosovo. As noted by Bechev (2012), Kosovo plays a vital role in maintenance of stability and togetherness among Albanians in the Balkans. Any prospective political/economic unrest in Kosovo can therefore easily spread over to other Albanians' settled territories, thereby destabilizing most states in the Balkan, and with that, a threat to Turkey's political influence. The same also applies to Macedonia which has had a previous history of ethnic and religious sensitivities. In fact, the presence of huge Albanian populations in Macedonia and more than $90 \%$ in Kosovo means that any crisis in these countries can easily draw the attention of Greece and Serbia (Pope, 2010).

Given the fact that Serbia and Greece are often in the opposing ends of Turkey's regional political maneuvers, the latter would definitely not dream of the presence of an anti-Turkish regional alliance pitting Greece, Serbia and Bulgaria. The country thus remains with no choice other than using geoeconomics to bolster its political influence on Albania and the other Albanians' settled territories of Macedonia and Kosovo. This is why Turkish political players are keen on pushing for a progressive economic support for, interconnectedness and cooperation among Albanians across the three countries of Albania, Kosovo and Macedonia (Mitrovic, 2014).

Apart from any trade imbalances, the larger Balkan region still does not feature among the top trading partners to Turkey as would be expected. For instance, the European Union and a large number of European countries have seen their economic/trade relations with Turkey improve at the expense of those of most Balkan states. The EU still remains Turkey's biggest trade partner and such non-Albanians' settled countries like Serbia still ranks high among Turkey's trade partners ahead of Albania, Macedonia and Kosovo. It can therefore be possibly argued that Turkey is yet to exhaust its geoeconomics potential in the above three countries.

\section{Conclusion}

Emboldened by the significance of the Balkans region in politics, the new Turkish foreign policy strategy, under the stewardship of AKP and the strategic views of Ahmet Davatoglu and his doctrine, "Strategic Depth", Turkey has once against re-established itself as a force to reckon with in as far as the political control of Balkan states is concerned. As indicated in the detailed discussion above, Turkey is increasingly using geoeconomics values such as foreign direct investments, signing of free trade agreements and other forms of economic support to cement its political influence on Albania, Kosovo and Macedonia. Critical in Turkey's continued use of geoeconomics is not only the strengthening of the country's political influence, but also the maintenance of greater level of stability in these regions to fend off prospective threats from Greece and Serbia. Progressive trade imbalances in the economic-trade relations between Turkey and the above countries however, imply that Turkey might not be effectively playing with the card of geoeconomics in the large Balkan region.

\section{References}

[1] Akcakar, B. (2007). Turkey's New European Era: Foreign Policy on the Road to EU Membership. New York: Rowman \& Littlefield

[2] Bal, I. (2004). Turkish Foreign Policy in Post Cold War Era. York: Universal Publishers

[3] Bechev, D. (2012). Turkey in the Balkans: Taking a Broader View. Insight Turkey, 14(1), 131-146

[4] Blitz, B. (2006). War Change in the Balkans: Nationalism, Conflict and Cooperation. Cambridge: Cambridge University press

[5] Bryman, A. (2004). Social Research Methods ( $2^{\text {nd }}$ ed), Oxford: Oxford University Press

[6] Buyukcolak, K. (1999). War of Projects: Turkish-Greek Rivalry in the Balkans in the Post-Cold War Period. Turkish Review of Balkan Studies, 4, 133-135

[7] Dautivic, M. (2011). Turkish Foreign Policy in the Balkans. RUSI Newbrief, 31 (1), 12-14

[8] Davutoglu, A. (2008). Turkey's Foreign Policy Vision: An Assessment of 2007. Insight Turkey, 10(1), 77-96

[9] Davutoglu, A. (2009). Principles of Turkish Foreign Policy. Speech at SETA Foundations Washington D. C. Branch. December 8 
[10] Deringil, S. (2004). Turkish Foreign Policy During the Second World War: An Active Neutrality. Cambridge: Cambridge University press

[11] Elsie, R. (2010). Historical Dictionary of Albania. New York: Rowman \& Littlefield

[12] Grigoriadis, I. (2010). The Davutoglu Doctrine and Turkish Foreign Policy. Hellenic Foundation for European and Foreign Policy Working Paper. 8, 1-11

[13] Hale, W. (2012). Turkish Foreign Policy, 1774-2000. London: Routledge

[14] Kiniklioglu, S. (2011). Turkey's Neighborhood Policy: Reintegration into Multiple Regions. In Bechev, D. What Does Turkey think? European Council on Foreign Relations, s. 63-68

[15] Kosebalaban, H. (2011). Turkish Foreign Policy: Islam, Nationalism, and Globalization. New York: Palgrave Macmillan

[16] Larrabee, S (2010). Turkey's New Geopolitics. Survival, 52(2), 157-180

[17] Mitrovic, M. (2014). Turkish Foreign Policy Towards the Balkans: The Influence of Traditional Determinants on Davutoglu's Conception of Turkey-Balkan Relations. GeT MA Working Paper Series, 10., 3-69 http://edoc. huberlin. de/series/getmaseries/2014-10/PDF/10. pdf

[18] Murinson, A. (2006). The Strategic Depth Doctrine of Turkish Foreign Policy. Middle Eastern Studies, 42(6), 945-964

[19] Oktav, O. (2013). Turkey in the 21st Century: Quest for a New Foreign Policy. London: Ashgate Publishing

[20] Oksuz, H. (2007). Turkey's Balkan Policy (1923-2007). Turkish Review of Balkan Studies. 12, 129-186

[21] Ozcan, M. (2008). Harmonizing Foreign Policy: Turkey, the EU and the Middle East. New York: Ashgate Publishing

[22] Pope, H. (2010). Pax Ottoman? The Mixed Success of Turkey's New Foreign Policy. Foreign Affairs Essay, Nov/Dec

[23] Rubin, B. \& Kirisci, K. (2001). Turkey in World Politics: An Emerging Multiregional Power. London: Lynne Rienner Publishers

[24] Szigetvári, T. (2012). Turkey is back: Turkish interest on the Western Balkans. EU Frontier Study 9, 1-18

[25] Uzer, U. (2010). Identity and Turkish Foreign Policy: The Kemalist Influence in Cyprus and the Caucasus. New York: I. B. Taurus

[26] Winrow, G. (1993). Where East Meets West: Turkey and the Balkans. Exeter: institute for European Defense and Strategic Studies 